\title{
Surgical parameter assessment using two Phacoemulsification Systems for grade I to IV cataracts
}

\section{Evaluación de los parámetros quirúrgicos empleando dos plataformas de facoemulsificación en cataratas grado I a IV}

\author{
Roberto González-Salinas ${ }^{*}$, Claudia Corredor-Ortega², Manuel Garza-León ${ }^{3}$, Marla Álvarez-Padilla²,
} Ana S. Serrano-Ahumada², Fátima Rubio-Tijerina², José A. Martínez-Cano ${ }^{2}$ and Juan P. Olivares-de Emparan ${ }^{2}$

${ }^{1}$ Research Department, Asociación para Evitar la Ceguera en México I.A.P., Mexico City; ${ }^{2}$ Anterior Segment Surgery Department, Asociación para Evitar la Ceguera en México I.A.P., Mexico City; ${ }^{3}$ Health Science Division, University of Monterrey, NL. Mexico.

\begin{abstract}
Aim: To compare the cumulative dissipated energy (CDE), aspiration fluid and aspiration time used during phacoemulsification using two surgical platforms. Methods: Consecutive eyes from patients undergoing cataract surgery were included. Lens opacities were graded from NO1NC1 to NO6NC6 using the LOCS III classification. Two platforms were evaluated: 1.Centurion ${ }^{\ominus}$ system with active-fluidics. 2. Infiniti Vision System with gravity-fluidics. Cumulative dissipated energy (CDE), aspiration time $(A T)$ and mean estimated aspiration fluid (EAF) were registered and compared. Results: $A$ total of 216 eyes were evaluated. Mean age $\pm S D$ was $78.3 \pm 9.8$ years (range 57 to 92). Significant differences were evidenced for overall CDE per nuclear density for cataracts grade II to IV ( $p=0.031, p=0.045$ and $p=0.032$ respectively). Aspiration time showed a significant disparity for cataracts graded II and III ( $p=0.024$ and $p=0.001$ ), as the Estimated Aspiration Fluid $(p=0.001$ and $p=0.042$ respectively). All differences favoured the active-fluidics configuration group. Conclusions: Active-Fluidics System demonstrated to be more effective than Gravity-fluidics system for cataracts grade II-IV phacoemulsification.
\end{abstract}

Key words: Cataract surgery. Phacoemulsification. Active-fluidics. Gravity-fluidics. Surgical parameters. Cumulative dissipated energy.

\section{Resumen}

Objetivo: Comparar la energía disipada acumulada (CDE), fluido aspirado y tiempo de aspiración utilizado durante la cirugía de catarata por facoemulsificación usando 2 plataformas. Métodos: Se incluyeron los ojos de pacientes consecutivos programados para ser sometidos a cirugía de catarata. Las opacidades del cristalino fueron clasificadas desde N01NC1 a NO6NC6 utilizando el sistema de clasificación de opacidades del cristalino (LOCS III). Se asignaron 2 plataformas: 1) fluídica activa del Centurion ${ }^{\oplus}$ y 2) fluídica por gravedad de Infiniti". Se registraron y compararon la energía disipada acumulada (CDE), el tiempo de aspiración utilizado y el fluido aspirado estimado. Resultados: Un total de 216 ojos fueron evaluados. La edad media $\pm D E$ fue de $78.3 \pm 9.8$ años (rango 57 a 92). Se observó una diferencia estadísticamente significativa en la CDE para cataratas grado II a IV ( $p=0.031, p=0.045$ y $p=0.032$, respectivamente). El tiempo de aspiración mostró una disparidad significativa para cataratas grado II y III ( $p=0.024$ y $p=0.001$, respectivamente), así como el fluido aspirado

\section{Correspondence:}

*Roberto Gonzalez-Salinas

Vicente García Torres, 46

Barrio San Lucas, Del. Coyoacán Date of reception: 13-04-2018

C.P. 04030, Mexico City, Mexico Date of acceptance: 15-10-2018

E-mail: dr.gonzalezsalinas@apec.com.mxＤOI: 10.24875/RMOE.M18000045

0187-4519/O 2018 Sociedad Mexicana de Oftalmología. Publicado por Permanyer México. Este es un artículo Open Access bajo la licencia CC BY-NC-ND (http://creativecommons.org/licenses/by-nc-nd/4.0/). 
estimado ( $p=0.001$ y $p=0.042$, respectivamente). Todas las diferencias favorecieron al grupo con la plataforma de fluídica activa. Conclusiones: El sistema de fluidica activa demostró ser más eficiente que la fluídica por gravedad en facoemulsificación de cataratas grado II a IV.

Palabras clave: Cirugía de catarata. Facoemulsificación. Fluídica activa. Fluídica por gravedad. Parámetros quirúrgicos. Energía disipada acumulada.

\section{Introduction}

The increase in global population in addition to a longer life expectancy impose major challenges for current Health Systems due to a raise in age-related pathologies, such as cataracts ${ }^{1,2}$. Moreover, despite late efforts to reduce the existing cataract backlog, it remains the leading cause of blindness worldwide ${ }^{3}$.

Currently, phacoemulsification is the preferred surgical technique in high income countries ${ }^{4,5}$, and has significantly contributed to make cataract extraction one of the most safe and cost-effective procedures in medicine $e^{6,7}$. Nowadays, patients' expectations are on the rise and cataract surgeons aim to obtain the best attainable postoperative refractive outcome; using more precise methods for intraocular lens (IOL) power calculation, improved new technologies and innovations in IOL design, as well as more effective phacoemulsification systems ${ }^{8-10}$.

Phacoemulsification principle is based on mechanical cutting of the lens nucleus using an oscillating needle tip. ${ }^{9}$ Until 2005, longitudinal ultrasound was the only technology available; however, the amount of ultrasound power required to remove a hard cataractous lens in traditional phaco implied a substantial risk for corneal endothelial cells. Nonetheless, torsional phaco produces needle tip lateral movements, effectively reducing the amount of ultrasound delivered, while decreasing the phaco tip repellent effect on the nuclear fragments ${ }^{8,9}$. Transversal ultrasound was recently introduced combining the longitudinal and lateral movement, thus creating an elliptical motion increasing the system's efficacy ${ }^{11}$.

Evidence has shown a torsional phaco superior efficacy when compared to longitudinal phaco overall performance, by reducing the amount of cumulative dissipated energy $(\mathrm{CDE})$ delivered to the eye; resulting in shorter rehabilitation time, reduced inflammatory response, lower complication rates and enhanced visual outcome $2,10,11$.

\section{Objective}

The aim of this study was to compare the overall efficacy of two phacoemulsification platforms, both with longitudinal and torsional ultrasound features, the Active-Fluidics Centurion ${ }^{\circledR}$ system and the Gravity-Fluidics Infiniti ${ }^{\circledR}$ Intelligent Phaco (IP) System for grade I to IV cataracts.

\section{Methods}

The present longitudinal, experimental and comparative study was approved by the Internal Review Board of Asociación para Evitar la Ceguera Hospital. All procedures conformed to the tenets of the Declaration of Helsinki. Before surgical procedures were performed, all participants agreed and signed a written informed consent.

We included cataract patients who underwent surgery at Queretaro Visual Center, Queretaro, Mexico, from February 2015 to February 2017.

Enrolled patients were assigned to one of two surgical configurations, active or gravity fluidics. Active-fluidics configuration comprised using the Centurion ${ }^{\circledR}$ Vision System with Active Fluidics ${ }^{\mathrm{TM}}$ with a $0.9 \mathrm{~mm}$ ABS $45^{\circ}$ Intrepid Balanced tip (Novartis Laboratories, Basel, Switzerland). For Gravity-fluidics configuration, we used the Infiniti ${ }^{\circledR}$ Vision System and a $0.9 \mathrm{~mm}$ ABS Mini-Flared $45^{\circ}$ Kelman tip (Novartis Laboratories, Basel, Switzerland). In both groups the $0.9 \mathrm{~mm}$ Ultra infusion sleeve was used.

Cataracts were graded before randomisation by comparison with standardised Lens Opacities Classification System III (LOCS III) into one of four groups, namely I to IV (IV being equivalent to NO5 and NO6 of the LOCS III) $)^{12}$.

\section{Patients}

Key inclusion criteria included patients of 50 years of age and older with lens opacities NO1NC1 to NO6NC6 undergoing phacoemulsification surgery and $\overline{I O L}$ implantation. Exclusion criteria included corneal pathology, contact lens wear history, glaucoma, ocular trauma and previous ocular surgery. 


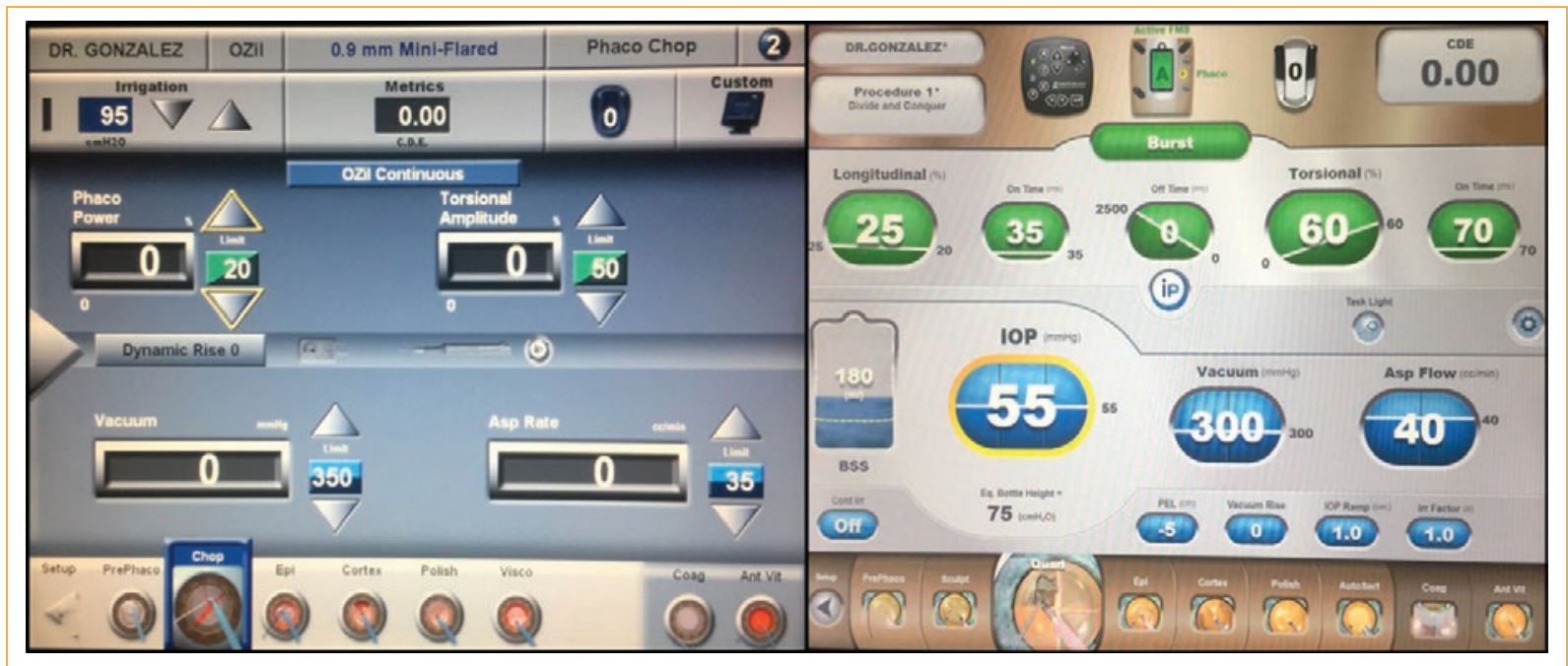

Figure 1. Interface display of the two Phacoemulsification Systems.

\section{Surgical technique}

All surgeries were performed by a single surgeon (RGS) using a standard horizontal or vertical chop technique under topical anaesthesia. Routine surgical technique with $2.4 \mathrm{~mm}$ clear corneal incision and 5.0 to $5.5 \mathrm{~mm}$ manually created capsulorrhexis using Duovisc $^{\circledR}$ (sodium hyaluronate 3\%-chondroitin sulfate 4.0\% with sodium hyaluronate $1.0 \%$ ) ophthalmic viscosurgical device (OVD), was carried out. Phacoemulsification was performed using the surgical configuration allocated during randomisation. Fluidic parameters were set to $350 \mathrm{mmHg}$ vacuum limit, and $40 \mathrm{~mL} / \mathrm{min}$ aspiration flow rate. Ultrasound parameters were set at $35 \%$ linear power with $60 \%$ torsional amplitude. After cataract removal and cortical material aspiration, all patients had in-the-bag IOL implantation.

\section{Outcome measures}

The intraoperative parameter selected as the primary outcome measure was the cumulative dissipated energy $(\mathrm{CDE})$, displayed automatically on the interface of both phacoemulsification systems and measured in percent-seconds, as depicted in figure 1. Additionally, data analysed included aspiration time, and estimated fluid; all of them automatically calculated by both platforms.

CDE was calculated using the following equation: $\mathrm{CDE}=$ mean phaco power $\mathrm{x}$ phaco time. For torsional US, $C D E=$ mean torsional amplitude phaco $\times 0.4$. The 0.4 constant is used to compensate for differences in the working parameters of the phacoemulsification system.
Both equations are in accordance with the phaco unit manufacturer guidelines and with previous studies ${ }^{10,13}$.

\section{Statistical analysis}

Continuous and categorical variables are displayed as means \pm standard deviation (SD) and percentages, respectively. Differences between continuous variables were assessed using a t-student test, or Mann-Whitney test depending on variable distribution. Differences between categorical variables were analysed employing Fisher's exact test. Both ANOVA and Kruskal-Wallis tests were employed for multiple comparisons between cataract densities depending on variable distribution. $p$ values $<0.05$ were considered to be statistically significant. Gaussian distribution was determined using the D'Agostino-Pearson omnibus normality test for all variables. Statistical analysis was performed using the Statistical Package for Social Sciences (SPSS) software (version 20, SPSS, Inc., Chicago, IL, USA). In addition, the Prism GraphPad software (Prism Inc. version 6.0) was employed for data graphs and layouts.

\section{Results}

A total of 216 eyes from 216 patients, 122 in the Active-Fluidics group and 94 in the Gravity-Fluidics group were enrolled in the study. Clinical and demographic data are summarised on table 1. The two groups were similar in terms of age and gender; and no statistically significant differences were evidenced. 
Overall CDE data is presented in table 2, depicting the CDE values of cataract graded I to IV. On table 3, a comparison of surgical parameters between groups according to nuclear density grade is depicted.

Figure 2 shows the overall CDE per nuclear density (LOCS III) where statistically significant differences were evidenced for cataract grade II to IV ( $p=0.031, p=0.045$ and $p=0.032$ respectively).

Aspiration time according to nuclear density is represented in figure 3 , where statistically significant differences were found between groups for cataracts grades II and III ( $p=0.024$ and $p=0.001$ respectively).

Estimated fluid used is represented in figure 4. Statistically significant differences were found between platforms for cataracts grade II and III according to nuclear opacity ( $p=0.001$ and $p=0.042$ respectively).

\section{Discussion}

The introduction of torsional ultrasound has significantly contributed to make cataract surgery more effective and safe by reducing risks associated to traditional longitudinal ultrasound; therefore, promoting faster rehabilitation time and better visual acuity. Reducing total ultrasound power during surgery is widely known to decrease endothelial cell loss precipitated by the procedure $^{9-15}$. The aim of our study was to compare the surgical efficacy of two phacoemulsification platforms featuring both longitudinal and torsional ultrasound.

Three different mechanisms of surgically induced trauma have been recognised during phacoemulsification - a mechanical component due to direct manipulation of the tissues and instruments inside the eye, ultrasound power and, fluid dynamics ${ }^{16}$. The mechanical component has not been of interest in previous studies because of the challenges to assess it and its dependence on the surgeons' learning curve. Nevertheless, by standardising all procedures to one single surgeon, the mechanical component - as a cofounder for the statistical analyses presented - is of no concern in our study.

Cumulative dissipated energy has been the main outcome assessed in recent papers comparing different types of phacoemulsification systems $s^{9-11,16-18}$. Solomon et al. found a statistically significant difference in $\operatorname{CDE}(p<0.001)$ favouring the Active-Fluidic configuration compared to Gravity-Fluidics ${ }^{17}$. In accordance with these findings, Oh et al. reported a CDE reduction in the active-fluidics configuration $(p=0.017)^{18}$, and Chen and collaborators demonstrated a $38.2 \%$ reduction in CDE $(p<0.001)^{13}$.

By stratifying our study population by nuclear density, we intended to assess whether differences in the
Table 1. Clinical and demographic data of included patients per group

\begin{tabular}{|c|c|c|c|}
\hline $\begin{array}{l}\text { Clinical } \\
\text { parameter }\end{array}$ & Active-Fluidics & Gravity-Fluidics & *ip value \\
\hline Age (years) & $67.22 \pm 10.80$ & $62.0 \pm 12.38$ & 0.279 \\
\hline Minimum & 57 & 58 & $\frac{c}{\sigma}-$ \\
\hline Maximum & 91 & 92 & - \\
\hline Gender (M/F) & $54 / 68$ & $43 / 51$ & (C) \\
\hline $\begin{array}{l}\text { * Mann-Whitney tes } \\
\text { M: male; F: female. }\end{array}$ & & & $\frac{\frac{1}{d}}{\frac{\frac{1}{n}}{a}}$ \\
\hline
\end{tabular}

Table 2. Overall CDE values, cataracts grade I to VI according to LOCS II

\begin{tabular}{|c|c|c|c|}
\hline $\begin{array}{l}\text { Nuclear } \\
\text { Density }\end{array}$ & Active-Fluidics & Gravity-Fluidics & * g value \\
\hline $\begin{array}{l}\text { Grade I } \\
\text { Media } \pm \text { SD } \\
\text { Range }\end{array}$ & $\begin{array}{c}0.78 \pm 0.13 \\
0-4.08\end{array}$ & $\begin{array}{c}0.95 \pm 1.21 \\
0-4.71\end{array}$ & $\frac{E}{0.786}$ \\
\hline $\begin{array}{l}\text { Grade II } \\
\text { Media } \pm \text { SD } \\
\text { Range }\end{array}$ & $\begin{array}{c}2.25 \pm 1.43 \\
0.96-6.15\end{array}$ & $\begin{array}{l}3.61 \pm 2.3 \\
1.26-10.5\end{array}$ & 0.031 \\
\hline $\begin{array}{l}\text { Grade III } \\
\text { Media } \pm \text { SD } \\
\text { Range }\end{array}$ & $\begin{array}{c}5.39 \pm 3.15 \\
2.1-14.22\end{array}$ & $\begin{array}{l}8.07 \pm 2.3 \\
1.9-15.31\end{array}$ & 0.045 \\
\hline $\begin{array}{l}\text { Grade IV } \\
\text { Media } \pm \text { SD } \\
\text { Range }\end{array}$ & $\begin{array}{l}12.6 \pm 0.85 \\
5.19-39.57\end{array}$ & $\begin{array}{c}16.75 \\
10.22-24.03\end{array}$ & 0.032 \\
\hline
\end{tabular}

*Paired t test was performed to detect differences between groups.

systems' efficacy could be found among varying nuclear cataract grades. A significant difference on CDE delivery was evidenced for cataracts grades $1 \mathrm{I}$ to IV ( $p=0.031, p=0.045$ and $p=0.032$ respectively), favouring the Active-Fluidics group. Few other studies have compared the same phacoemulsification platforms and stratified their population according to nuclear densities, most of them reporting only total CDE reduction in the whole group ${ }^{13,16,17}$.

Similar to our findings $\mathrm{O}$ et al. reported lower $\mathrm{CDE}$ for cataract grades III and above ( $P=0.033)$. While providing very valuable information, with a total population of 412 subjects - even larger than our study - Oh and colleagues did not randomised subjects prior to the intervention, having a higher proportion of denser nuclei in the Active-Fluidics group ${ }^{18}$.

In our study, lower aspiration time was recorded for cataract grades II and III subgroups ( $p=0.024$ and $p=0.001$ ), and less estimated fluid ( $p=0.001$ and 
Table 3. Comparison of surgical parameters between groups according to nuclear density grade

\begin{tabular}{|c|c|c|c|c|}
\hline Parameter & Grade & Active-Fluidics & Gravity-Fluidics & p value* \\
\hline \multirow[t]{4}{*}{ CDE (percent-seconds) } & Grade I & $1.88 \pm 0.18$ & $1.31 \pm 0.21$ & $0.279 \stackrel{\infty}{-}$ \\
\hline & Grade II & $2.72 \pm 0.46$ & $3.12 \pm 0.40$ & $0.031 \frac{1}{d}$ \\
\hline & Grade III & $5.874 \pm 0.73$ & $7.92 \pm 0.90$ & 0.045 \\
\hline & Grade IV & $13.72 \pm 1.96$ & $18.71 \pm 2.11$ & 0.032 \\
\hline \multirow[t]{4}{*}{ AT (mseg) } & Grade I & $247.4 \pm 25.18$ & $247.9 \pm 11.2$ & 0.250 () \\
\hline & Grade II & $299.3 \pm 38.1$ & $333.5 \pm 43.1$ & 0.024 \\
\hline & Grade III & $263.9 \pm 39.1$ & $310.8 \pm 47.0$ & $0.001 \frac{}{n}$ \\
\hline & Grade IV & $312.9 \pm 31.6$ & $304.1 \pm 45.3$ & $0.575 \frac{0}{3}$ \\
\hline \multirow[t]{4}{*}{$\mathrm{EF}(\mathrm{mL})$} & Grade I & $84.69 \pm 16.18$ & $88.1 \pm 15.4$ & 0.237 \\
\hline & Grade II & $91.1 \pm 11.8$ & $104.64 \pm 16.0$ & 0.001 \\
\hline & Grade III & $93.4 \pm 18.4$ & $105.61 \pm 22.0$ & 0.042 운 \\
\hline & Grade IV & $106.2 \pm 20.1$ & $110.1 \pm 25.6$ & $0.181 £$ \\
\hline
\end{tabular}

$\mathrm{CDE}=$ Cumulative Dissipated Energy, $\mathrm{AT}=$ Aspiration time, $\mathrm{EF}=$ Estimated Fluid used (all expressed in means \pm standard deviation). *Unpaired $\mathrm{t}$ test was performed to detect statistically significant differences between groups.

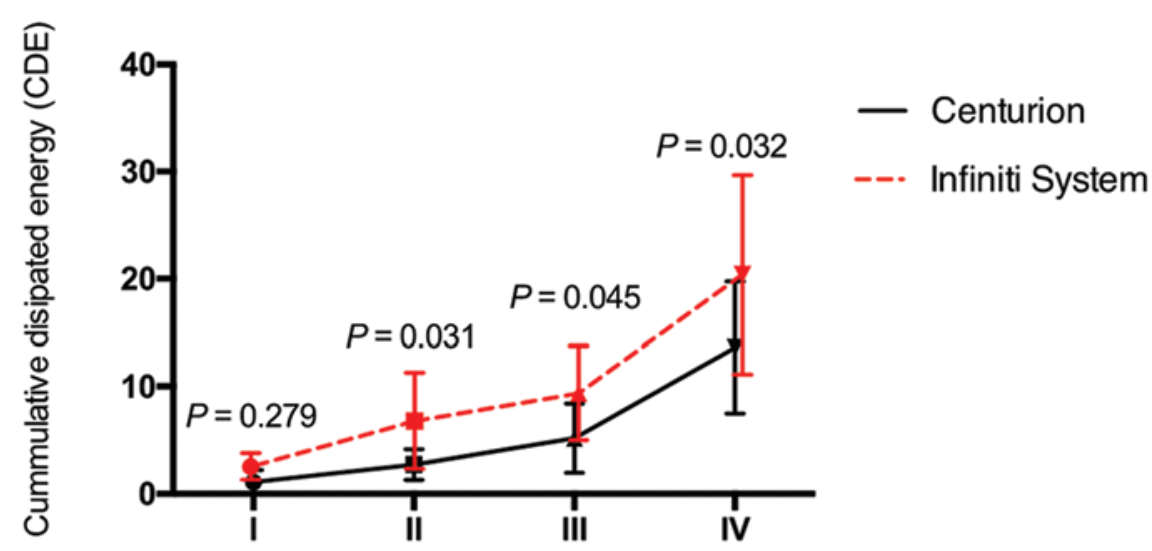

\section{Nucleus density according to LOCS II classification system}

Figure 2. CDE count expressed in Mean ( \pm SD) according to nuclear density (LOCS III = Lens Opacities Classification System II).

*Unpaired t test was performed to detect statistically significant differences between groups.

$p=0.042)$ using the Active-Fluidics configuration. These results concur with previously reported data employing solely grade II and III cataracts ${ }^{16}$.

Out of the three main outcomes, only CDE was significantly lower in the Active-Fluidics group for cataracts grade IV $(p=0.032)$. Aspiration time and estimated fluid were similar in both groups for cataracts grade I and IV. The only stratus where no difference was found for CDE was grade I cataracts. While no positive correlation was found between nuclear hardness and the overall system's efficacy; our findings suggest the active fluidics configuration has better overall performance for cataracts grade II and above. 


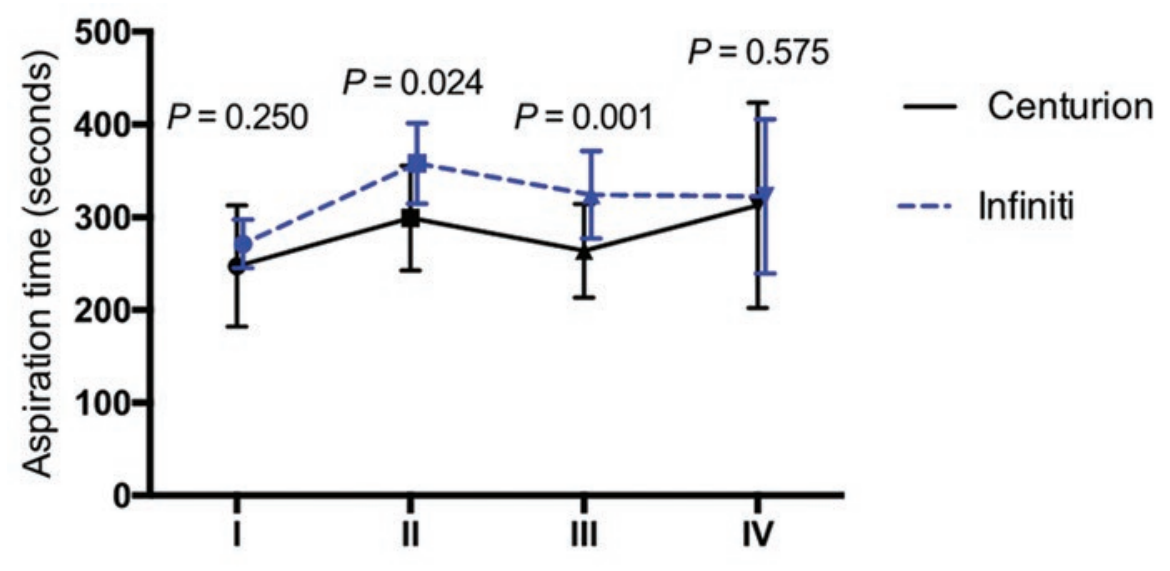

Nucleus density LOCS II classification system

Figure 3. Aspiration time (AT) Mean ( \pm SD) according to nuclear density (LOCS III = Lens Opacities Classification System II).

*Unpaired t test was performed to detect statistically significant differences between groups.

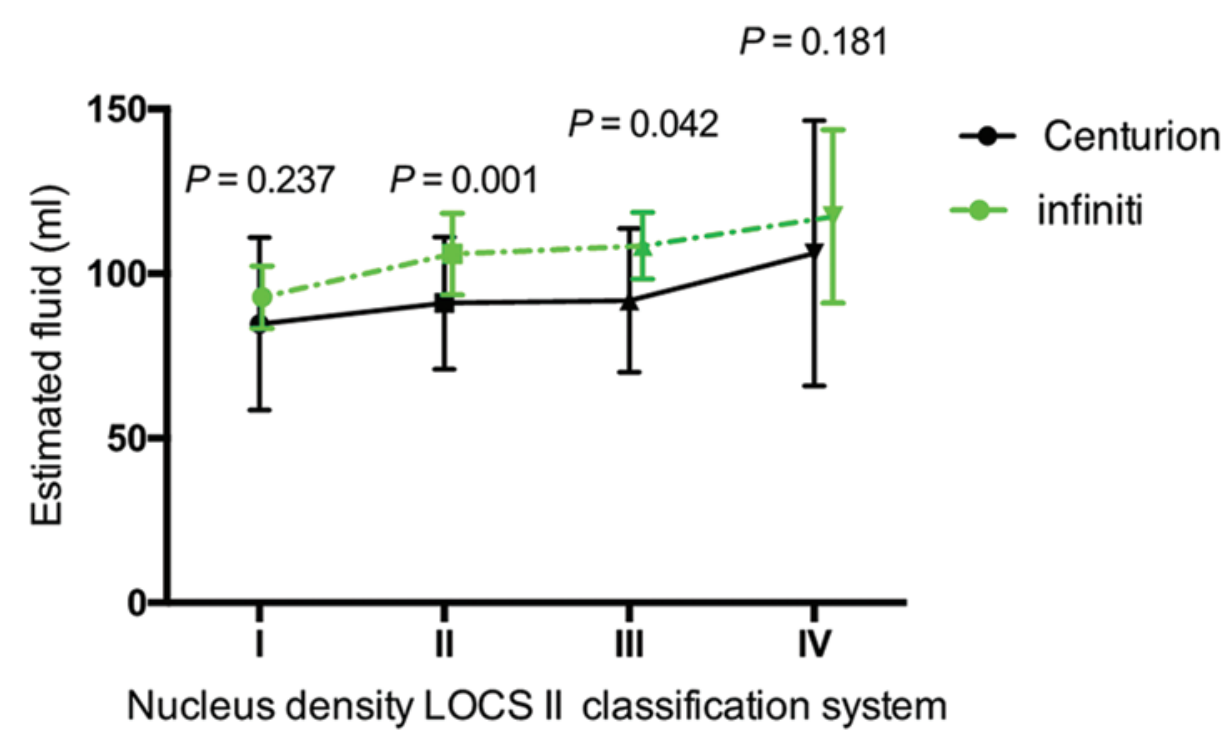

Figure 4. Estimated fluid according to nuclear density (EF). Mean ( \pm SD); LOCS III = Lens Opacities Classification System II.

*Unpaired t test was performed to detect statistically significant differences between groups.

Some limitations of our study should be noted; we employed different phaco tips with each platform, which may play a role on the overall surgical efficacy for both systems. Recently reported data by Khokhar et al. suggest that the new balanced tip performed phacoemulsification more effectively when compared to the 45-degree conventional tip, especially in hard cataracts, requiring higher energy and prolonged phacoemulsification time ${ }^{19}$.We theorise that both, the type of Phacoemulsification System employed and the phaco tip used may play a role on the overall systems efficacy. 


\section{Acknowledgements}

We acknowledge the invaluable contribution to this research study of physicians including the following: Alberto Ansart Berges, Martín Ayala Flores, Francisco Chávez-Mendez, Patricia Culebro Solano, José Feregrino Ortiz, Martín Gallegos Duarte, Vinicio García Solís, Elizabeth Gómez-Pimienta, Roberto González Origel, Miguel Huerta García, Jorge A. León Carrera, Rocío Meré Alcocer, Lorley Miller Eagan, Jorge Pacheco Padrón, Jaime Palacios Alcocer, Lourdes Páramo Figueroa, Judith Peñaflor Siller, Nicolás Perea Ortega, Hector Randolph Rodríguez, Manuel Sáenz-de-Viteri Siso, Manuel Sáenz-de-Viteri Vázquez, Roberto Varela Gress, and Patricia Vázquez Rojas.

\section{Conflicts of interest}

The authors do not have any economic, proprietary or financial interest to disclose in the publication of this paper.

\section{Financial support}

No financial support was provided to carry out this study.

\section{Ethical disclosures}

Protection of human and animal subjects. The authors declare that no experiments were performed on humans or animals for this study.

Confidentiality of data. The authors declare that they have followed the protocols of their work center on the publication of patient data.

Right to privacy and informed consent. The authors have obtained the written informed consent of the patients or subjects mentioned in the article. The corresponding author is in possession of this document.

\section{References}

1. Lundström M, Barry P, Henry $Y$, Rosen P, Stenevi U. Evidence-based guidelines for cataract surgery: guidelines based on data in the European Registry of Quality Outcomes for Cataract and Refractive Surgery database. Journal of Cataract \& Refractive Surgery. 2012 Jun 1;38(6):1086-93.

2. Reuschel $A$, Bogatsch $H$, Barth $T$, Wiedemann R. Comparison of endothelial changes and power settings between torsional and longitudinal phacoemulsification. Journal of Cataract \& Refractive Surgery. 2010 Nov 1;36(11):1855-61.

3. Pascolini D, Mariotti SP. Global estimates of visual impairment: $2010 . \mathrm{Br}$ J Ophthalmol. 2012;96:614-8.

4. Riaz $Y$, de Silva $S$, Evans J. Manual small incision cataract surgery (MSICS) with posterior chamber intraocular lens versus phacoemulsification with posterior chamber intraocular lens for age-related cataract. Cochrane Collab. 2013;(10).

5. Spalton D, Koch D. The constant evolution of cataract surgery. BMJ. 2000;321:1304.

6. Lansingh VC, Carter MJ, Martens M. Global cost-effectiveness of cataract surgery. Ophthalmology. 2007;114:1670-8.

7. Abell RG, Vote BJ. Cost-Effectiveness of Femtosecond Laser-Assisted Cataract Surgery versus Phacoemulsification Cataract Surgery. Ophthalmology. 2014;121:10-6.

8. McAlinden C, Wang Q, Pesudovs K, Yang X, Bao F, Yu A, et al. Axial length measurement failure rates with the IOLMaster and Lenstar LS 900 in eyes with cataract. PLoS One. 2015 Jun 10;10(6):e0128929.

9. Christakis PG, Braga-Mele RM. Intraoperative performance and postoperative outcome comparison of longitudinal, torsional, and transversal phacoemulsification machines. J Cataract Refract Surg. 2012;38:234-41.

10. Rẹkas M, Montés-Micó R, Krix-Jachym K, Kluś A, Stankiewícz A, Ferrer-Blasco T. Comparison of torsional and longitudinal modes using phacoemulsification parameters. Journal of Cataract \& Refractive Surgery. 2009 Oct 1;35(10):1719-24.

11. Assaf A, Roshdy MM. Comparative analysis of corneal morphological changes after transversal and torsional phacoemulsification through $2.2 \mathrm{~mm}$ corneal incision. Clin Ophthalmol. 2013;7:55-61.

12. Chylack LT, Wolfe JK, Singer DM, Leske MC, Bullimore MA, Bailey IL, et al. The lens opacities classification system III. Archives of ophthalmology. 1993 Jun 1;111(6):831-6.

13. Chen M, Anderson E, Hill G, Chen JJ, Patrianakos T. Comparison of cumulative dissipated energy between the Infiniti and Centurion phacoemulsification systems. Clinical ophthalmology (Auckland, NZ). 2015; 9:1367.

14. Sorrentino FS, Matteini S, Imburgia A, Bonifazzi C, Sebastiani $\bar{A}$, Parmeggiani F. Torsional phacoemulsification: A pilot study to revise the "harm scale" evaluating the endothelial damage and the visual acuity after cataract surgery. PloS one. 2017 Oct 26;12(10):e0186975.

15. Venkatesh $R$, Van Landingham SW, Khodifad AM, Haripriya A,Thiel CL, Ramulu $\mathrm{P}$, et al. Carbon footprint and cost-effectiveness of cataract surgery. Current opinion in ophthalmology. 2016 Jan 1;27(1):82-8.

16. Gonzalez-Salinas R, Garza-Leon M, Saenz-de-Viteri M, Solis-S JC, Gulias-Cañizo R, Quiroz-Mercado H. Comparison of cumulative dissipated energy delivered by active-fluidic pressure control phacoemulsification system versus gravity-fluidics. Int Ophthalmol. 2017;1-7.

17. Solomon KD, Lorente R, Fanney D, Cionni RJ. Clinical study using a new phacoemulsification system with surgical intraocular pressure control. J Cataract Refract Surg. 2016;42:542-9.

18. Oh LJ, Nguyen CL, Wong E, Wang SS, Francis IC. Prospective study of Centurion $^{\circledR}$ versus Infiniti ${ }^{\circledR}$ phacoemulsification systems: surgical and visual outcomes. International journal of ophthalmology. 2017;10(11):1698.

19. Khokhar S, Aron N, Sen S, Pillay G, Agarwal E. Effect of balanced phacoemulsification tip on the outcomes of torsional phacoemulsification using an active-fluidics system. Journal of Cataract \& Refractive Surgery. 2017 Jan 1;43(1):22-8 